\title{
HYDROLASE ACTIVITIES IN BRAIN OF NEUROLOGICAL MUTANTS: CEREBROSIDE GALACTOSIDASE, NITROPHENYL GALACTOSIDE HYDROLASE, NITROPHENYL GLUCOSIDE HYDROLASE AND SULPHATASE ${ }^{1}$
}

\author{
D. M. Bowen ${ }^{2}$ and N. S. RADIN \\ Mental Health Research Institute, University of Michigan, Ann Arbor, \\ Michigan 48104
}

(Received 23 May 1968)

\begin{abstract}
The brains of 17-day-old quaking and jimpy mice were compared with those of the corresponding normal phenotypes. The concentrations of cerebroside and sulphatide were found to be markedly lower in the affected mutants, while the relative amounts of ceramide and free fatty acid appeared normal.

(2) The concentration of cerebroside glactosidase was not significantly abnormal in the jimpy mice but was about $\mathbf{1 7}$ per cent lower in quaking mice. In contrast, the relative amount of the enzyme that could be dispersed by sonication was considerably higher in the jimpy animals. It is suggested that this increase is a causative factor in the aetiology of the latter disease.

(3) The concentrations of other acid hydrolases were determined, as well as the relative amounts dispersible by sonication. No difference was seen between the phenotypes with NPGalH, NPGluH, and nitrocatechol sulphate hydrolase.

(4) An improved solvent system for the TLC detection of ceramide in brain lipids is described.
\end{abstract}

A NUMBER of neurological mutants of the mouse central nervous system have been characterized genetically and histologically (SIDMAN, GREEN and APPEL, 1965). In the quaking and jimpy mutants, the content of myelin, cerebroside and cerebroside sulphate is greatly reduced (SIDMAN, Dickie and APPEL, 1964; BAumanN, JACQue, Pollet and HARPIN, 1968). It seemed possible that the cerebroside-cleaving enzyme, cerebroside galactosidase (cerebrosidase), is over-active in the affected animals. The excessive activity could be the result of overproduction of the enzyme or of a high proportion of physiologically active enzyme. Cerebrosidase is largely particle-bound, apparently in lysosomes (BOWEN and RADIN, 1968). Lysosomal enzymes are known to become partially or completely dispersed when the suspended particles are stressed physically (SAwant, Shibko, KumTa and TAPPEL, 1964). Such dispersion may take place in the intact animal and the proportion of the enzyme that is dispersed may determine the functional activity of each lysosomal enzyme. It is thus possible that the level of total cerebrosidase could be normal or even subnormal in the mutants, but that the functional activity is high.

An investigation of these possible explanations is reported here, together with a comparison with other acid hydrolases that are apparently lysosomal.

\footnotetext{
${ }^{1}$ This work supported in part by a Public Health Service Grant, No. NB-03192, from the National Institute for Neurological Diseases and Blindness.

${ }^{2}$ Present address: Unilever Research Laboratory, Isleworth, Middlesex, England.

Abbreviations used: NPGalH, $p$-nitrophenyl $\beta$-D-galactoside hydrolase; NPĞluH, $p$-nitrophenyl $\beta$-D-glucoside hydrolase.
} 


\section{MATERIALS AND METHODS}

The mice were obtained from The Jackson Laboratory, Bar Harbor, Maine through the courtesy of Mrs. Priscilla W. Lane. The animals were decapitated at 17 days of age and the heads were frozen and shipped in dry ice. Jimpy $(j p)$ is sex-linked and is maintained with the linked marker, tabby $(T a)$. The jimpy mice were of two kinds: $+j p / \mathrm{Y}$ with controls $++/ \mathrm{Y}$, and $T a j p / \mathrm{Y}$ with controls $T a+/ \mathrm{Y}$. The quaking mice were of the genotype $q k / q k$ and the controls were either heterozygotes $(q k /+)$ or homozygous normal $(+/+)$, the two being indistinguishable visually.

The procedures for processing the brains are largely described in another paper (BOWEN and RADIN, 1969). Lipid analyses were made by treating a portion of the brain homogenates with chloroform-methanol, washing the extract with dilute $\mathrm{KCl}$ solution and separating the lipids by TLC on Silica Gel G.

The cerebrosidase content of the brain homogenates was determined by incubation with galactoselabelled cerebroside, following enzymic digestion and acid precipitation of the enzyme. In the experiments on dispersibility, the homogenates (prepared from pools of three brains) were diluted with additional buffer to $12 \mathrm{ml} / \mathrm{g}$ brain and sonicared with a dipping probe. Centrifugation at 100,000 $g$ for $1 \mathrm{hr}$ yielded the supernatant and nondispersible fractions. Since the brains had been frozen prior to analysis, the cytosol fraction had to be included with the dispersible fraction. The supernatant fraction was assayed without digestion and acid precipitation because relatively little endogenous cerebroside was present.

The assays for the other acid hydrolases were carried out as previously described (BowEN and RADIN, 1969), except that the glucosidase was assayed at $\mathrm{pH} 5$ and the arylsulphatase was assayed according to the procedure of SELLINGER and HIATT (1968). Linearity with respect to amount of enzyme was good except for sulphatase in total homogenate and supernatant liquid. The nonlinearity for sulphatase was similar in both diseased and normal animals and is apparently due to the presence of phosphate, which is inhibitory (DIXON and WEBB, 1964).

\section{RESULTS AND DISCUSSION}

Lipid analyses. In confirmation of the work of previous workers, the content of cerebrosides and sulphatides was found to be extremely low while the other major lipids were similar in proportion. This extends the previous observations to mice containing the $\boldsymbol{T a}$ trait and mice of both sexes. TLC with chloroform-methanolacetic acid $(90: 2: 8)$ showed that only a trace amount of nonhydroxy ceramide occurs in the lipids; no difference could be seen between the mutants and their controls. (This useful solvent mixture gives a good separation of hydroxyceramide $\left[R_{F} 0 \cdot 17\right]$, ceramide $\left[R_{F} 0.46\right]$ and cholesterol $\left[R_{F} 0 \cdot 74\right]$.) TLC with hexane-ether-acetic acid $(80: 20: 3)$ showed distinct spots of similar intensity, corresponding to free fatty acids. The ceramide content was of interest because this lipid is the product of cerebrosidase action and the fatty acid content was of interest because this enzyme is markedly activated by free fatty acids.

Total cerebrosidase activities. The data in Table 1 show that there is little difference between the jimpy and control mice (lines 3-6) but that a significant decrease (17 per cent, $P<0.01$ ) exists in the quaking mice. The cerebrosidase activity observed in the quaking mice does not appear to account for the low cerebroside content in these mice and the low enzyme value may reflect a feedback response to a deficiency in cerebroside level. There appears to be no significant difference in cerebrosidase content between the sexes.

The incubation system used in the above assays did not contain oleic acid, which was later shown to augment the observed activity of the rat brain enzyme considerably. The assay procedure used here involves digestion with pancreatic enzymes, with consequent formation of free fatty acids and the resultant cerebrosidase preparation contains free fatty acids. It therefore seemed possible that the preparation from the quaking mice showed lower activity because of the lower concentration of lipids in their brains. This point was checked by re-assaying the cerebrosidase in the stored 
TABLE 1.- TOTAL CEREBRosidase ACTIVTTY OF MUTANT MICE

\begin{tabular}{|c|c|c|c|c|c|c|c|c|c|c|c|}
\hline \multirow{2}{*}{ Genotype } & \multicolumn{9}{|c|}{$\mathrm{m} \mu$ moles galactose released $/ \mathrm{hr} / \mathrm{g}$ wet brain } & \multirow{2}{*}{$\begin{array}{c}\text { Average } \\
\text { body } \\
\text { wt.(g) }\end{array}$} & \multirow{2}{*}{$\begin{array}{c}\text { Average } \\
\text { brain } \\
\text { wt.(mg) }\end{array}$} \\
\hline & \multicolumn{6}{|c|}{ Individual brains } & \multicolumn{2}{|c|}{$\begin{array}{c}\text { Pooled } \\
\text { brains }\end{array}$} & Average & & \\
\hline Quaking & $342^{1}$ & $272^{1}$ & $342^{1}$ & $296^{2}$ & $297^{2}$ & 326 & 305 & 284 & 308 & $6 \cdot 44$ & 364 \\
\hline Control & $391^{2}$ & $346^{1}$ & $370^{1}$ & $406^{2}$ & $425^{2}$ & 354 & 359 & 325 & 372 & $7 \cdot 19$ & 383 \\
\hline Jimpy & $297^{8}$ & $318^{8}$ & $340^{3}$ & $328^{4}$ & $338^{5}$ & $383^{5}$ & 362 & 312 & 335 & $7 \cdot 44$ & 337 \\
\hline Control & $345^{8}$ & $355^{3}$ & $352^{4}$ & $336^{6}$ & $376^{6}$ & & 299 & 335 & 343 & $7 \cdot 53$ & 362 \\
\hline Tabby jimpy & $341^{4}$ & $373^{6}$ & $374^{8}$ & $306^{7}$ & & & & & 349 & 5.63 & 328 \\
\hline Tabby control & $369^{4}$ & $455^{5}$ & $307^{7}$ & & & & & & 377 & $6 \cdot 52$ & 353 \\
\hline
\end{tabular}

The superscripts identify littermates. The numbers in italics identify females. The activities of the pooled brains were calculated by adding the activities in the supernatant and nondispersible fractions.

preparations in the presence of an additional $350 \mu \mathrm{g}$ of oleic acid. Both quaking and control cerebrosidase were increased by about 90 per cent (the loss of activity after 40 days of storage was equal too, about 8 per cent). The enzyme from the other mice showed even better stability and a similar amount of activation.

The cerebrosidase assay procedure involves discarding two fractions which ordinarily contain a small amount of activity. This point was checked with these mice and no difference was observed between phenotypes ( 10 per cent of the activity was in the nondigestible fraction and 1 per cent was in the acid-soluble fraction).

The dispersibility of acid hydrolases. The total activity of arylsulphatase, NPGluH and NPGalH in every group of mice was quite similar (Table 2). This contrasts with the decrease found for cerebrosidase in quaking animals (Table 1).

In another paper (BowEN and RADIN, 1969) we showed that the hydrolase activities in the cytosol of rat brain were considerably less than the dispersible activities. This was confirmed for cerebrosidase in the case of an extra group of quaking and control mice (the activities in the cytosol were about the same). Thus the activities in the supernatant fraction (Table 2) can be assumed to be primarily of the dispersible type.

The fraction of activity that is dispersible by sonication is quite different for each enzyme, as shown with rat brain. The data for NPGluH are not shown because the

TABLE 2.-ACID HYDROLASES OF MUTANT MICE AND THEIR DISPERSTBILITY

\begin{tabular}{|c|c|c|c|c|c|c|c|}
\hline \multirow{2}{*}{ Genotype } & \multicolumn{3}{|c|}{ Total activity ( $\mu$ moles/hr/g brain) } & \multicolumn{4}{|c|}{$\begin{array}{l}\text { Ratio of activities (supernatant/ } \\
\text { nondispersible) }\end{array}$} \\
\hline & Sulphatase & NPGalH & NPGluH & Sulphatase & NPGalH & Cereb & rosidase \\
\hline Quaking & $66(96)$ & $20(105)$ & $8 \cdot 4(86)$ & $\begin{array}{l}3 \cdot 0 \\
2 \cdot 7\end{array}$ & $\begin{array}{l}1 \cdot 3 \\
1 \cdot 2\end{array}$ & $\begin{array}{l}0 \cdot 20 \\
0 \cdot 17\end{array}$ & \\
\hline Control & $58(98)$ & $22(92)$ & $8 \cdot 9(92)$ & $\begin{array}{l}2 \cdot 6 \\
3 \cdot 1\end{array}$ & $\begin{array}{l}1 \cdot 2 \\
0 \cdot 9 \\
1 \cdot 3\end{array}$ & $\begin{array}{l}0.17 \\
0.14 \\
0.15\end{array}$ & \\
\hline Jimpy & $\begin{array}{l}67 \\
60\end{array}(91)$ & $\begin{array}{l}24 \\
22\end{array}(91)$ & ${ }^{8 \cdot 4}(82)$ & $\begin{array}{l}4 \cdot 4 \\
3 \cdot 3\end{array}$ & $\begin{array}{l}1 \cdot 2 \\
1 \cdot 4\end{array}$ & $\begin{array}{l}0.24 \\
0.24\end{array}$ & $\begin{array}{l}0.22 * \\
0.21 *\end{array}$ \\
\hline Control & $\begin{array}{l}66 \\
59\end{array}(94)$ & $\begin{array}{l}25 \\
21\end{array}(91)$ & $\frac{8 \cdot 1}{-}(88)$ & $\begin{array}{l}4 \cdot 2 \\
3 \cdot 6\end{array}$ & $\begin{array}{l}1 \cdot 2 \\
1 \cdot 4\end{array}$ & $\begin{array}{l}0.18 \\
0.16\end{array}$ & $\begin{array}{l}0.13^{*} \\
0.15^{*}\end{array}$ \\
\hline
\end{tabular}

Total activities are derived from assay of total homogenate. Numbers in brackets are percentage recoveries in the supernatant and nondispersible fractions, compared with the total homogenate. Pairs of values are the result of analysing two sets of three brains of each type. The numbers in italics identify the females.

* These values obtained with four extra groups of mice; all other data obtained with the same mice as Table 1, 'pooled brains'. 
supernatant contained so little activity (ratio $<0 \cdot 17$ ). Thus this brain enzyme is very similar to the corresponding enzyme in rat liver (BECK and TAPPEL, 1968). Both cerebrosidase and NPGluH appear to be bound to relatively large membrane fragments, whereas much of the sulphatase and NPGalH is attached to material which is readily rendered dispersible.

No difference between mutants and controls was seen with respect to the fraction that was dispersible except for the cerebrosidase activities. The quaking mice showed a ratio that was 28 per cent higher than that of the controls, while the ratio for the jimpy mice was 47 per cent higher. These differences cannot be attributed to an assay error arising from abnormal amounts of endogenous cerebroside in some samples as the observed specific activities were about the same with 5 and $10 \mathrm{mg}$ portions of brain. As a further check of the validity of the assays, the extra groups of mice (shown by the asterisk) were assayed with the use of the 'lipase'- $\mathrm{pH} 3$ procedure for both supernatant and nondispersible fractions. The results were similar to those shown in the table.

When the dispersible cerebrosidase is compared on an absolute rather than relative basis, the quaking and both genotype control mouse groups exhibit the same average activities (48, 45 and 50 units). The absolute activity in the dispersible fraction of the jimpy mice was 72 units, 44 per cent higher. This difference may mean that the deficiency in myelin and cerebroside content in the jimpy brains is due to a demyelinative process, while that in the quaking mice is due to a deficiency in deposition. Evidence that the jimpy disorder is one of demyelination comes from the appearance of sudanophilic lipid droplets and macrophages coincident with the onset of myelination. No such signs are detectable in quaking mice and preliminary data from this laboratory indicate that there is a deficiency in cerebroside biosynthesis (MORELL and RADIN, unpublished).

In another paper (BOWEN and RADIN, 1969) we offered evidence for the involvement of the cytosol activity in normal, physiological functioning and now we propose, on the basis of the above observations, that the dispersible activity functions in pathological states, possibly acting to initiate demyelination. In this connection, it is of interest that in the case of naphthyl esterases of human brain, there is a marked increase in the dispersible fraction obtained from the plaques of multiple sclerosis and Schilder's disease (BARRON and BERNSOHN, 1965).

Acknowledgement-The authors would like to express grateful appreciation to Mrs. SUSAN BowEN for assistance in carrying out this work.

\section{REFERENCES}

Barron K. D. and Bernsohn J. (1965) Ann. N.Y. Acad. Sci. 122, 393.

Baumann N., Jacque C., Pollet S. and Harpin M. L. (1968) European J. Biochem. 4, 340.

BeCK C. and TAPPEL A. K. (1968) Biochim. biophys. Acta 151, 159.

Bowen D. M. and RADIN N. S. (1968) Biochim. biophys. Acta 152, 599.

Bowen D. M. and RADIN N. S. (1969) J. Neurochem. 16, to be published.

Dixon M. and Webr E. C. (1964) In Enzymes p. 59. Academic Press, New York.

Sawant P. C., Shibko S., Kumta U. S. and TAPpel A. C. (1964) Biochim. biophys. Acta $85,82$.

Sellinger O. Z. and Hiatt R. A. (1968) Brain Res. 7, 191.

Sidman R. L., Dickie M. M. and APPel S. H. (1964) Science 144, 309.

Sidman R. L., Green M. C. and Appel S. H. (1965) In Catalog of the Neurological Mutants of the Mouse, Harvard Univ. Press, Cambridge, Mass. 